\title{
An Impact of Biofeedback Training on the Effectiveness of Cognitive Training in Stroke Patients
}

\author{
Natalya V. Kozlova \\ Ekaterina A. Cexmejstruk \\ Inna V. Atamanova \\ Tatyana E. Levickaya \\ Dilara G. Nazmetdinova \\ Tomsk State University, \\ Russia, Tomsk
}

\section{Влияние БОС-тренинга на эффективность когнитивных тренировок у пациентов с инсультом}

\author{
Наталья В. Козлова \\ Екатерина А. Цехмейструк \\ Инна В. Атаманова \\ Татьяна Е. Левицкая \\ Дилара Г. Назметдинова
}

Национальный исследовательский Томский государственный университет, Россия, Томск

Corresponding author.E-mail:mea2887@mail.ru

Introduction. The clinical significance of cognitive impairments remaining in patients with acute cerebrovascular accidents (stroke) in the second rehabilitation period actualizes the need for their correction. The technique of cognitive training shows a high degree of cognitive function recovery, but negative emotional states that may occur in patients during rehabilitation may reduce its positive effect. In this regard, the use of biofeedback (BFB) training to stabilize the patients' psycho-emotional state before cognitive training can increase its effectiveness.

Purpose. To evaluate the impact of BFB-training on the effectiveness of cognitive training in patients with acute cerebrovascular disorders in the second rehabilitation period.

Design. 41 post-stroke patients (ischemic stroke) in their late recovery period with varying degrees of cognitive impairments, not reaching the level of dementia, completed a course of standard rehabilitation and psychological treatment, including cognitive training sessions. Of these, 20 patients (the experimental group), before cognitive training, addition- 
ally underwent a BFB-training based on the skin conductance parameter. Psychodiagnostic evaluation conducted before and after the rehabilitation course included a study of visual and auditory-speech memory, volume, distribution, and attention switching, the level of depression, as well as unconscious and conscious anxiety.

Results. After the course of rehabilitation and psychological treatment, the experimental group showed a statistically significant improvement in all cognitive functions and indicators of psycho-emotional state. Positive dynamics in the control group is observed only in the cognitive sphere. The level of cognitive functions in the experimental group after the rehabilitation course was significantly higher than in the control one.

Conclusions. An additional inclusion of BFB-training in the course of rehabilitation and psychological treatment helps to increase the effectiveness of cognitive training by stabilizing the psycho-emotional state, as well as by providing a positive impact of biofeedback methods on cognitive functions.

Keywords: post-stroke patients; cognitive function impairments; cognitive training; biofeedback.

Введение. Клиническая значимость сохраняющихся когнитивных нарушений у пациентов с острым нарушением мозгового кровообращения во втором реабилитационном периоде актуализирует необходимость их коррекции. Метод когнитивных тренировок показывает высокую степень восстановления когнитивных функций, однако негативные эмоциональные состояния, которые иногда возникают у пациентов в процессе реабилитации, могут снижать его положительное влияние. Использование БОСтренинга для стабилизации психоэмоционального состояния перед когнитивными тренировками может повысить их эффективность.

Цель. Оценить влияние БОС-тренинга на эффективность когнитивных тренировок у пациентов с острым нарушением мозгового кровообращения во втором реабилитационном периоде.

Дизайн. 41 пациент с ишемическим инсультом в позднем восстановительном периоде с разной степенью когнитивного снижения, не достигающего уровня деменции, прошел курс стандартных реабилитационно-психологических мероприятий, содержащий когнитивные тренировки. Из них 20 пациентов (экспериментальная группа) дополнительно перед тренировками проходили БОС-тренинг по параметру электрической кожной проводимости. Психодиагностическая оценка, проводимая до и после курса реабилитации, включала исследование зрительной и слухоречевой памяти, объема, распределения и переключения внимания, уровня депрессии, а также неосознаваемой и осознаваемой тревоги.

Результаты. После курса реабилитационно-психологических мероприятий в экспериментальной группе отмечено статистически значимое улучшение всех когнитивных функций и показателей психоэмоционального состояния. Положительная динамика в контрольной группе наблюдалась только в когнитивной сфере. Уровень когнитивных функций в экспериментальной группе после курса реабилитации был достоверно выше, чем в контрольной. 
Выводы. Дополнительное включение БОС-тренинга в курс реабилитационнопсихологических мероприятий способствует повышению эффективности когнитивных тренировок за счет стабилизации психоэмоционального состояния, а также положительного влияния методов биоуправления на когнитивные функции.

Ключевые слова: пациенты с острым нарушением мозгового кровообращения; снижение когнитивных функиий; когнитивные тренировки; биологическая обратная связь.

\section{Introduction}

A high prevalence of cognitive impairment after stroke determines the relevance of research in this area. It is cognitive impairments that mainly result in a deterioration of post-stroke patients' recovery prognosis, exacerbating the risk of recurrent stroke, and a significant decrease in their quality of life (Prokopenko, Mozhejko, \& Koryagina, 2014). It is known that active recovery of cognitive functions occurs within the first six months after a stroke and most of the scientific studies regard this period of recovery (Ostankova \& Habarova, 2016; Naumenko, Gromova, \& Preobrazhenskaya, 2017; Guzeva V. I. et al., 2018). However, in the late recovery period, according to the literature, from 11 to $31 \%$ of the remaining cognitive impairments are observed (Guzeva V.I. et al., 2018; Levin, Usol'ceva, \& Yunishchenko, 2007), so a decrease in interest in this period must be viewed unjustified.

A high significance of restoring cognitive functions and difficulties emerging during this process give rise to a reasonable question about how to correct them. One of the most actively developing areas today is a cognitive training technique and its positive impact has been confirmed in numerous studies (Prokopenko et al., 2014; Prokopenko et al., 2017; Gamito et al., 2017; Jaeggi, Karbach, \& Strobach, 2017; Zlobina, Epaneshnikova, \& Zinov'eva, 2018; Prokopenko, Bezdenezhnykh, Mozheyko, \& Petrova, 2018). The appearance of a large number of computer programs for implementing this method indicates its availability and effectiveness (Prokopenko et al., 2014; Prokopenko et al., 2017; Gamito et al., 2017). At the same time, in recent years the problem of improving the outcomes of cognitive training has attracted researchers' attention as well. In particular, it has been found that applying transcranial electrical stimulation enhances working memory training (Richmond, Wolk, Chein, \& Olson, 2014; Wang et al., 2019).

It is known that the process of post-stroke recovery is a quite complex and lengthy one, therefore, patients may experience various types of adverse emotional states (Ermakova, 2018). A lack of rapid success generates depressive reactions, an inability to perform ordinary actions creates a feeling of frustration, changes in their somatic state lead to an increased feeling of anxiety, etc. It is worth noting that these states may be situational in their essence and do not reach a clinical level of their manifestation, but their presence can have a negative impact on the effectiveness of the rehabilitation process in general and cognitive training in particular. For example, depressive symptoms have been found to reduce the effectiveness of cognitive training (Felix, Du, Taylor, \& Rebok, 2019). 
In our opinion, a method for correcting such dynamic negative emotional states could be a biofeedback training aimed at reducing post-stroke patients' emotional tension and improving their adaptive state (Dyomin \& Poskotinova, 2014; Epaneshnikova \& Kabataev, 2017). Therefore, additionally including the biofeedback training into the course of rehabilitation and psychological treatment can increase the effectiveness of cognitive training by stabilizing such patients' psycho-emotional state, as well as by having a positive impact of biofeedback techniques on cognitive functions (Sutarto, Wahab, \& Zin, 2013; Trofimova, Kayutina, Isajchev, Chernorizov, \& Varako, 2018; Marinina, 2019).

\section{Methods}

\section{Participants}

The study sample consisted of 41 people ( 25 men and 16 women) aged from 45 to 63 years (57.0 \pm 3.21 ) who had an acute cerebrovascular accident (onset of an ischemic stroke was six months or longer prior) and were in their second rehabilitation period (the late recovery stage). All the patients had cognitive impairments of varying degrees of severity, not reaching the state of dementia. All participants had the highest level of education. Participants gave their informed consent form for additional research procedures.

\section{Procedure}

The experimental base was the Neurological Department of the Tomsk Research Institute of Balneology and Physiotherapy of the Federal Siberian Research Clinical Centre under the FMBA of Russia (Tomsk), where the study participants underwent a course of rehabilitation for 3 weeks (21 days), which, in addition to physiotherapy procedures, included cognitive training sessions. The choice of cognitive training programs was determined by the existing cognitive impairments in the patients and was aimed at restoring the visual memory and attention functions. The sessions were carried out daily ( 5 times a week) for 30 minutes by means of the CogniPlus software (CPS, SCHUHFRIED GmbH; the NBACK and SELECT (S3) programs).

\section{Testing}

The psychodiagnostic instruments involved the following techniques: Learning 10 Words by A.R. Luria (for evaluating one's direct memorizing as well as short- and long-term memory) (Rubinshtejn, 1999); the Hospital Anxiety and Depression Scale (HADS) (to assess one's level of anxiety and depression) (Zigmond \& Snaith, 1983); the NS-PsychoTest computer complex (Neurosoft Company, Russia): Memory for Numbers (to evaluate visual memory) (Balin, Gajda, \& Gerbachevskij, 2000), the Schulte-Platonov Red-Black Tables (to assess attention volume, distribution and switching) (Shapar', Timchenko, \& Shvydchenko, 2007), M. Lüscher's eight-color test (to evaluate one's unconscious anxiety) (Sobchik, 2001). 


\section{Statistical Analyses}

Each of the patients was randomly assigned to either the experimental group $(n=20)$ or the control group $(n=21)$ based on simple randomization with random number generator. In experimental group $(n=20)$ in addition to cognitive training, underwent a biofeedback (BFB) training as well. The sessions were conducted using the Biofeedback $2000 \mathrm{x}$-pert software and hardware system (SCHUHFRIED GmbH; the JigsawPuzzle program) every day ( 5 times a week) for 15 minutes before cognitive training. The BFB-training was carried out based on the skin conductance parameter (SC) in parallel with registering the study participants' uncontrolled physiological indicators: the level of electrical skin resistance (ESR), hand temperature (HT), heart rate (HR). The choice of skin conductance as a parameter to be controlled is due to its relationship with conscious and unconscious emotional stimuli (Gordievskaya \& Gordievskij, 2014; Christopoulos, Uy, \& Yap, 2016).

Microsoft Excel (2010) and IBM SPSS Statistics v19 were used for statistical processing of the data collected. Testing the normality of the data distribution was performed applying the Shapiro-Wilks criterion. If there was a normal distribution of the parameter, the data were presented as a mean and a standard deviation $(M \pm S D)$. If the distribution was different from normal, the data were presented as a median $(M d n)$ and an interquartile range in a format of $M d n[Q 1, Q 2]$, where $Q 1$ is the lower quartile and Q2 is the upper quartile.

To determine significant differences in the paired samples (before and after psychological treatment) under the normal distribution law, the Student's paired t-test $(t ; p)$ was used. If the parameter distributions in the dependent samples being analyzed differed from the normal one, the Wilcoxon T-test $(Z ; p)$ was applied. If the parameter distribution in the two independent samples in question differed from the normal one, the non-parametric Mann-Whitney U-test $(U ; Z ; p)$ was used. To compare the effectiveness of psychological treatment and rehabilitation, the variable Es was introduced, which was calculated as the ratio of the difference in the indicator values before and after psychological treatment to the indicator with a higher value (the comparison of variables was performed as that of independent series). To reveal the relationship between the indicators if differed from the normal distribution, the Spearman $r_{s}$-test $\left(r_{j} ; p ; n\right)$ was used.

\section{Results}

Before the beginning of the rehabilitation and psychological treatment concerned, no statistically significant differences in psychological indicators were found between the groups $(p>0.05)$. Patients in the control and experimental groups were characterized by a decrease in visual and auditory-speech memory, a low level of attention volume, distribution and switching. Indicators of their emotional sphere did not reach negative values; however, $10 \%$ (2 patients) in each group were diagnosed with a subclinical level of anxiety and depression.

After the rehabilitation and psychological treatment in the control group, there was a statistically significant positive dynamics in the attention indicators within the low level. Visual memory reached the lower norm, and auditory-speech memory improved 
within the reduced values (see Table 1). There were no statistically significant changes in the indicators of the emotional sphere.

The experimental group after the rehabilitation and psychological treatment was characterized by statistically significant positive dynamics for all the cognitive sphere indicators in question (see Table 1). Visual memory indicators reached their average norm, auditory-speech memory approached the standard values, and attention indicators corresponded to the level below the average. Statistically significant positive dynamics of the emotional sphere was observed in the indicators of unconscious and conscious anxiety and depression. After the rehabilitation and psychological treatment in the experimental group there were no patients with a subclinical level of anxiety and depression.

Table 1

The effectiveness of rehabilitation and psychological treatment in the experimental and control groups (Mdn [Q1, Q2], scores)

\begin{tabular}{|c|c|c|c|c|c|c|}
\hline & $\begin{array}{c}\text { Control group } \\
\quad(n=21) \\
\text { BEFORE, AFTER }\end{array}$ & $Z$ & $p$ & $\begin{array}{c}\text { Experimental } \\
\text { group }(n=20) \\
\text { BEFORE, AFTER }\end{array}$ & $Z$ & $p$ \\
\hline Visual memory & $\begin{array}{l}3[2,4.5] \\
5[4,6,5]^{\star}\end{array}$ & -3.648 & .000 & $\begin{array}{c}4[3,5.75] \\
7[6.25,73.5]^{\star}\end{array}$ & -4.053 & .000 \\
\hline Attention volume & $\begin{array}{c}83[57.5,106], \\
80[54.5,100.5]^{\star}\end{array}$ & -3.808 & .000 & $\begin{array}{l}81.5[57,90] \\
62[49,73.5]^{\star}\end{array}$ & -3.927 & .000 \\
\hline $\begin{array}{l}\text { Attention } \\
\text { distribution }\end{array}$ & $\begin{array}{l}155[117,168.5], \\
132[112,170]^{\star}\end{array}$ & -2.904 & .004 & $\begin{array}{c}136[100.25,160.5] \\
100[84.5,122.5]^{\star}\end{array}$ & -3.921 & .000 \\
\hline $\begin{array}{l}\text { Attention } \\
\text { switching }\end{array}$ & $\begin{array}{l}82[63,109.5], \\
71[45.5,83.5]^{*}\end{array}$ & -3.318 & .001 & $\begin{array}{c}79[54,94.5], \\
60,5[36.7,73.75]^{\star}\end{array}$ & -3.921 & .000 \\
\hline Immediate recall & $3[2,4], 4[3,5]^{\star}$ & -2.739 & .006 & $4[3,5], 6[4.25,6]^{*}$ & -3.100 & .002 \\
\hline $\begin{array}{l}\text { Number } \\
\text { of recalling all } \\
\text { the } 10 \text { words }\end{array}$ & $\begin{array}{l}0[0,0] \\
0[0,1]\end{array}$ & -2.236 & .025 & $0[0,0], 0[0,1]$ & -2.264 & .008 \\
\hline Delayed recall & $\begin{array}{c}5[3,5.5] \\
5[5,6]\end{array}$ & -2.074 & .038 & $\begin{array}{c}4[2.25,4] \\
6.5[4.25,8]\end{array}$ & -3.203 & .001 \\
\hline $\begin{array}{l}\text { Unconscious } \\
\text { anxiety }\end{array}$ & $\begin{array}{l}2[2,3] \\
3[2,3]^{\star}\end{array}$ & -1.542 & .123 & $\begin{array}{l}3[2.5,4] \\
1.5[1,2]^{*}\end{array}$ & -3.886 & .000 \\
\hline Anxiety & $\begin{array}{l}4[1.5,6] \\
2[1,5]^{\star}\end{array}$ & -1.145 & .252 & $\begin{array}{l}4[2,6] \\
1[1,2]^{\star}\end{array}$ & -3.336 & .001 \\
\hline Depression & $3[0,5], 5[1,3]^{\star}$ & -0.909 & .363 & $\begin{array}{c}3.5[3,5.75] \\
1[1,1.75]^{\star}\end{array}$ & -3.426 & .001 \\
\hline
\end{tabular}

Note. The Wilcoxon T-test; ${ }^{\star}$ means statistically significant differences between the groups.

Comparison of the psychodiagnostic test results for the two groups after the rehabilitation and psychological treatment revealed statistically significant differences in vi- 
sual memory $(U=63.50, Z=-3.905, p=.000)$, attention volume $(U=127, Z=-2.167$, $p=.03)$, attention distribution $(U=110, Z=-2.610, p=.009)$, attention switching $(U=132$, $Z=-2.037, p=.042)$, immediate recall $(U=94.50, Z=-3.097, p=.002)$, unconscious anxiety $(U=68.50, Z=-3.845, p=.000)$, conscious anxiety $(U=138.50, Z=-2.049, p=.034)$, depression $(U=136.50, Z=-2.134, p=.033)$. In the experimental group, attention indicators were significantly lower, which indicates a higher level of attention processes, while other psychological indicators also showed higher values compared to the control group results.

Cognitive training results also reveal a more pronounced positive dynamics in the experimental group. Patients of the experimental group achieved a higher level in the training programs; they demonstrated a higher rate and a better quality of responses (see Table 2).

\section{Table 2}

Comparison of the effectiveness of cognitive training in the experimental and control groups $(M d n[Q 1, Q 2]$, the level of training - scores; the average response rate - ms; the number of timely responses - scores)

\begin{tabular}{|c|c|c|c|c|c|c|}
\hline & & $\begin{array}{l}E s, \text { the experimental } \\
\text { group }(n=20)\end{array}$ & $\begin{array}{l}\text { Es, the control } \\
\text { group }(n=21)\end{array}$ & $U$ & $Z$ & $p$ \\
\hline $\begin{array}{l}\text { U } \\
\text { 岁 } \\
\text { 足 }\end{array}$ & The level of training & $-3[-3,-1.25]$ & $-2[-3.5,-1]$ & 121.00 & -2.965 & .041 \\
\hline \multirow{3}{*}{ 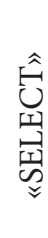 } & The level of training & $-4[-5.75,-2.25]$ & $0[-2,0]$ & 44.00 & -4.397 & .000 \\
\hline & $\begin{array}{l}\text { The average } \\
\text { response rate }\end{array}$ & $344[210.5,475.25]$ & $259[169.5,420.5]$ & 90.00 & -2.356 & .036 \\
\hline & $\begin{array}{l}\text { The number } \\
\text { of timely responses }\end{array}$ & $-42.5[-59,-28]$ & $-14[-24,-9]$ & 60.50 & -3.901 & .000 \\
\hline
\end{tabular}

Note. The Mann-Whitney U-test.

The BFB-training in the experimental group resulted in a decrease in the study participants' heart rate (HR) and skin conductance (SC) and an increase in their hand temperature (HT) and electrical skin resistance (ESR) (see Table 3). These changes indicate that the relaxation effect was obtained and the psycho-emotional state was improved.

\section{Table 3}

Dynamics of average values of psychophysiological indicators within the BFB relaxation training in the experimental group $(n=20)\left(M \pm S D\right.$; SC, ESR $\left.-\mathrm{ms} ; \mathrm{HT}-{ }^{\circ} \mathrm{C} ; \mathrm{HR}-\mathrm{bpm}\right)$

\begin{tabular}{ccccc}
\hline Indicators & $\begin{array}{c}\text { At the beginning } \\
\text { of the training }\end{array}$ & $\begin{array}{c}\text { At the end } \\
\text { of the training }\end{array}$ & $t$ & $p$ \\
\hline SC & $2.33 \pm 2.08$ & $1.55 \pm 1.02$ & -3.323 & .000 \\
ESR & $.003 \pm .006$ & $.067 \pm .28$ & 5.275 & .003
\end{tabular}


Table 3 (continued)

\begin{tabular}{ccccc}
\hline Indicators & $\begin{array}{c}\text { At the beginning } \\
\text { of the training }\end{array}$ & $\begin{array}{c}\text { At the end } \\
\text { of the training }\end{array}$ & $t$ & $p$ \\
\hline HT & $32.42 \pm 2.57$ & $33.41 \pm 1.82$ & -2.018 & .048 \\
HR & $76.03 \pm 9.99$ & $71.12 \pm 10.94$ & 2.542 & .020 \\
\hline
\end{tabular}

Note. Student's t-test.

In order to evaluate the effectiveness of rehabilitation and psychological treatment, we performed a correlation analysis between physiological indicators, data from the techniques used and cognitive training. A positive relationship was obtained between attention distribution $\left(r_{s}=.686, p=.001, n=20\right)$ and attention switching $\left(r_{s}=.467, p=.038, n=20\right)$ and skin conductance. Attention distribution was also positively related to heart rate $\left(r_{s}=.573, p=.003, n=20\right)$. Lower values of attention, characterizing a higher level of development of this process, were observed when the physiological values were decreasing, indicating a decrease in the activity of the sympathetic nervous system and a reduction in negative psycho-emotional states.

Correlations were revealed between hand temperature and immediate recall $\left(r_{s}=.490\right.$, $p=.028, n=20)$ and unconscious anxiety $\left(r_{s}=-.478, p=.033, n=20\right)$; therefore, the relaxation effect observed when the hand temperature increases, improves immediate memory and reduces anxiety.

The study participants' response rate was positively related to skin conductance $\left(r_{s}=.472, p=.036, n=20\right)$ and negatively with electrical skin resistance $\left(r_{s}=-.532, p=.016\right.$, $n=20$ ). The results obtained correspond to the knowledge about the effect of electrical skin activity on the response rate (Christopoulos et al., 2016).

\section{Discussion}

A statistically significant improvement in cognitive functions observed in the control and experimental groups is due to the direct impact of cognitive training aimed at correcting the attention and visual memory functions. An improvement in auditory and speech memorization that was not specifically affected is probably due to the "transfer" effect, which involves transferring the improvement in cognitive functioning to adjacent non-trainable cognitive functions (Velichkovsky, 2009). The effectiveness of using cognitive training to restore reduced cognitive functions in patients with acute cerebrovascular disorders is mainly due to neurodynamic disorders of cognitive processes.

The BFB-training based on the skin conductance parameter leads to stabilization of patients' psycho-emotional state before cognitive training, thereby increasing the effectiveness of the latter on. Additionally, the relaxation effect observed in the process of BFB-training contributes to the improvement of cognitive functions (Sutarto et al., 2013; Trofimova et al., 2018; Marinina, 2019). The relationship between cognitive functions, 
emotional state and physiological processes explains positive results of the rehabilitation and psychological treatment.

However, some limitations should be noted. First, our study has a relatively small sample size of participants. Increasing the sample will help to increase the statistical significance of the results in future studies. Second, we not used the location and type of stroke in patients. Probably, taking into account these features can influence the dynamics of changes in psychological parameters.

\section{Conclusions}

A purposeful impact on memory and attention processes by means of cognitive training using specialized programs causes positive dynamics not only in the cognitive functions that are actually trained, but also in those that are not in question, thereby expanding the area of positive influence on post-stroke patients' cognitive functioning. An additional inclusion of BFB-training in the course of rehabilitation and psychological treatment helps to increase the effectiveness of cognitive training by stabilizing the psycho-emotional state, as well as by providing a positive impact of biofeedback methods on cognitive functions. Working with the current psychological state of patients with acute cerebrovascular disorders before conducting rehabilitation and psychological treatment improves their quality and effectiveness.

\section{Acknowledgements}

The study was supported by the Russian Foundation for Basic Research, project \# 18-013-00937 "A biopsychosocial approach to rehabilitation of patients with cerebrovascular diseases: An integrative psychological model of health evaluation".

\section{References}

Balin, V.D., Gajda, V.K., \& Gerbachevskij, V.K. (2000). Workshop on general, experimental and applied psychology: Textbook. St. Petersburg: Piter. [In Russian]

Christopoulos, G., Uy, M., \& Yap, W. J. (2016). The body and the brain: Measuring skin conductance responses to understand the emotional experience. Organizational Research Methods, 22(1), 1-27. https://doi.org/10.1177/1094428116681073

Dyomin, D. B., \& Poskotinova, L. V. (2014). Physiological basis of the functional biofeedback methods. Human Ecology, 9, 48-59. [In Russian]

Epaneshnikova, N. V., \& Kabataev, M. V. (2017). New organizational and hardware-software technologies of neurorehabilitation intervention and evaluation of rehabilitation potential. Bulletin of the South Ural State University. Series «Psychology», 10 (3), 81-90. [In Russian]. https://doi.org/10.14529/ psy170308 
Ermakova, N.G. (2018). Psychological rehabilitation of patients after stroke in conditions of restorative treatment. Medical Psychology in Russia, 2, 9. [In Russian]. https://doi.org/10.24411/2219-82452018-12090

Felix, C., Du, S., Taylor, B., \& Rebok, G. (2019). Depressive symptoms: Hampering maintenance of cognitive training gains. Innovation in Aging, 3, S432-S433. https://doi.org/10.1093/geroni/igz038.1619.

Gamito, P., Oliveira, J., Coelho, C., Morais, D., Lopes, P., Pacheco, J., ... Barata, A. F. (2017). Cognitive training on stroke patients via virtual reality-based serious games. Disability and Rehabilitation, 39 (4), 385-388. https://doi.org/10.3109/09638288.2014.934925

Gordievskaya, N. A., \& Gordievskij, A. Y. (2014). Cognitive and psychophysiological process stabilization as a result of autogenous training classes. Samara Journal of Science, 2 (7), 21-23. [In Russian]

Guzeva, V.I., Bykova, O. N., Guzeva, V. V., Guzeva, O. V., Smirnova, V. V., \& Pavlova, N. V. (2018). Dynamics of recovery of speech and cognitive impairment in different periods of ischemic stroke. Bulletin of the Russian Military Medical Academy, 3 (63), 46-49. [In Russian]

Jaeggi, S., Karbach, J., \& Strobach, T. (2017). Enhancing brain and cognition through cognitive training. Journal of Cognitive Enhancement: Towards the Integration of Theory and Practice, 1 (4), 353-357. https://doi.org/10.1007/s41465-017-0057-9

Levin, O. S., Usol'ceva, N. I., \& Yunishchenko, N. A. (2007). Post-stroke cognitive impairment: Developmental mechanisms and treatment approaches. Difficult Patient, 5 (8), 29-36. [In Russian]

Marinina, D. V. (2019). Some aspects of the influence of biofeedback on cognitive function. In Yu. S. Shatskikh (Ed.)., Current trends and innovations in the development of Russian science (Pt. 4, pp. 53-57). Moscow: Pero. [In Russian]

Naumenko, A. A., Gromova, D. O., \& Preobrazhenskaya, I. S. (2017). Cognitive training and rehabilitation for patients with cognitive impairment. Doktor.Ru, 11 (140), 31-38. [In Russian]

Ostankova, Yu. V., \& Habarova, T. Yu. (2016). Cognitive disorders in patients with cerebral circulation disorders: psychodiagnostics and correction. Young Scientist, 1, 82-86. [In Russian]

Prokopenko, S. V., Bezdenezhnykh, A. F., Mozheyko, E. U., \& Petrova, M. M. (2018). A comparative clinical study of the effectiveness of computer cognitive training in patients with post-stroke cognitive impairments without dementia. Psychology in Russia: State of the Art, 11 (2), 55-67. https:// doi.org/10.11621/pir.2018.0205

Prokopenko, S. V., Dyadyuk, T. V., Mozhejko, E. Yu., Bezdenezhnyh, A. F., Koryagina, T.D., \& Anaj-Ool, T.S. (2017). Use of computer stimulating programs in patients with post-stroke cognitive impairmen. Neurology, Neuropsychiatry, Psychosomatics, 9 (3), 48-53. [In Russian]

Prokopenko, S. V., Mozhejko, E. Yu., \& Koryagina, T. D. (2014). The opportunities of cognitive training with use of specialized computer programs in poststroke patients. Neurological Journal, 19 (1), 20-24. [In Russian]

Richmond, L., Wolk, D., Chein, J., \& Olson, I. (2014). Transcranial direct current stimulation enhances verbal working memory training performance over time and near transfer outcomes. Journal of Cognitive Neuroscience, 26 (11), 2443-2454. https://doi.org/10.1162/jocn_a_00657

Rubinshtejn, S. Ya. (1999). Experimental methods of pathopsychology. Moscow: EKSMO-Press. [In Russian]

Shapar, V.B., Timchenko, A. V., \& Shvydchenko, V.N. (2007). Practical psychology. Tool. Rostov-onDon: Feniks. [In Russian] 
Sobchik, L. N. (2001). MCV-color selection method. Modified eight-color lusher test. Practical guide. St. Petersburg: Rech'. [In Russian]

Sutarto, A. P., Wahab, M.N., \& Zin, N. M. (2013) Effect of biofeedback training on operator's cognitive performance. Work, 44 (2), 231-243. https://doi.org/10.3233/WOR-121499

Trofimova, A. K., Kayutina, D. V., Isajchev, S. A., Chernorizov, A. M., \& Varako, N. A. (2018). Biofeedback technologies in the system of clinical-psychological diagnostics and neuro-rehabilitation. Question of Psychology, 2, 111-121. [In Russian]

Velichkovsky, B. B. (2009). Performance capabilities of cognitive training as a method of correcting age-related decline in cognitive control. Experimental Psychology, 2 (3), 78-91. [In Russian]

Wang, N., Ke, Y., Du, J., Liu, W., Kong, L., Zhao, X. J., ... Ming, D. (2019). High-Definition Transcranial Direct Current Stimulation (HD-tDCS) enhances working memory training. 41st Annual International Conference of the IEEE Engineering in Medicine and Biology Society (EMBC) (pp. 329-332). https://doi.org/10.1109/EMBC.2019.8856976

Zigmond, A. S., \& Snaith, R. P. (1983). The hospital anxiety and depressions. Acta Psychiatrica Scandinavica, 67 (6), 361-370. https://doi.org/10.1111/j.1600-0447.1983.tb09716.x

Zlobina, Yu. V., Epaneshnikova, N. V., \& Zinov'eva, N.P. (2018). Efficiency of cognitive trainings in patients with acute brain circulation in the acute period: Pilot study. Bulletin of the South Ural State University. Ser. "Psychology", 11(3), 64-73. [In Russian]. https://doi.org/10.14529/psy180308

Original manuscript received March 03, 2020 Revised manuscript accepted March 30, 2020

To cite this article: Kozlova, N. V., Cexmejstruk, E. A., Atamanova, I. V., Levickaya, T.E., \& Nazmetdinova, D. G. (2020). An impact of biofeedback training on the effectiveness of cognitive training in stroke patients. Lurian Journal, 1 (1), 129-139. DOI:10.15826/Lurian.2020.1.1.9 